Uralic studies, languages, and researchers

Edited by Sándor Szeverényi 
Studia uralo-altaica 54

Redigunt:

Katalin Sipőcz

András Róna-Tas

István Zimonyi 
Uralic studies, languages, and researchers

Proceedings of the $5^{\text {th }}$ Mikola Conference 19-20, September 2019

Edited by Sándor Szeverényi

Szeged, 2021 
(C) University of Szeged,

Department of Altaic Studies,

Department of Finno-Ugrian Philology

All rights reserved. No part of this book may be reproduced, stored in a retrieval system, or transmitted in any form or by other means, electronic, mechanical, photocopying, recording or otherwise, without the prior permission in writing of the author or the publisher.

Printed in 2021.

Printed by: Innovariant Ltd., H-6750 Algyő, Ipartelep 4.

ISBN 978-963-306-803-8 (printed)

ISBN 978-963-306-804-5 (pdf)

ISSN 0133-4239 (Print)

ISSN 2677-1268 (Online) 
Table of contents

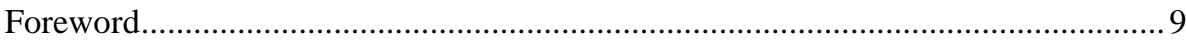

Sándor Szeverényi

Notes on Nicolaes Witsen and his Noord en Oost Tartarye. 11 Rogier Blokland

Undiscovered treasures: From the field research archive to the digital database......27 Beáta Wagner-Nagy, Chris Lasse Däbritz, and Timm Lehmberg

On the language use of the first Finnish medical text 45

Meri Juhos

Sajnovics, the responsible fieldworker 55

Sándor Szeverényi

The life and work of the Saami theologian and linguist: Anders Porsanger 71

Ivett Kelemen

The use and semantics of the Northern Mansi diminutive -riś $r \partial s$ ś 81

Bernadett Bíró

The event of "giving" and "getting" in Siberian Uralic languages 99

Katalin Sipöcz

A word-formational approach to neologisms in modern Northern Mansi

Susanna Virtanen

Word and stem repetitions in the heroic epic songs collected by Antal Reguly ..... 131 Mária Sipos

The use of body part terms in expressing emotions in Udmurt 149

Rebeka Kubitsch

The characteristics of responses given to compliments in Udmurt 173

Zoltán Németh

On some Chuvash-Mari shared lexemes and Agyagási's "Late Gorodets" hypothesis .. 185 Christopher Culver 
“Сувениры Севера" Minority identity and discourse. Representation of indigenous minorities of Northern Russia in the digital media. The case of Dudinka ........... 201 Zsuzsa Várnai and Ágnes Hámori

Reconsidering the Nganasan vowel system 229 László Fejes

New aspects in the study of Mari, Udmurt, and Komi-Permyak: The Typological Database of the Volga Area Finno-Ugric Languages 255 Erika Asztalos, Nikolett F. Gulyás, Laura Horváth, and Bogáta Timár Ethnosyntax in Siberian Uralic Languages (a project report) 275 Bernadett Bíró, Katalin Sipöcz, and Sándor Szeverényi 


\title{
Ethnosyntax in Siberian Uralic languages (project ${ }^{1}$ overview)
}

\author{
Sándor Szeverényi, Bernadett Bíró, and Katalin Sipőcz
}

University of Szeged

\section{Introduction}

It is a well-known fact that language interacts with the environment around it, in another words, "linguistic structure is formed, changed and influenced by different aspects of the human environment" (Busser 2015: 1). Recently, various subfields of linguistics have played a role in studies of extra-linguistic effects on language structures, such as sociolinguistics, ecolinguistics, cultural linguistics, and ethnosyntax.

The root of our intention can be found in the traditions of ethnolinguistics, which is "an interdisciplinary field based on linguistics and social anthropology which is concerned with the relationship between language and culture. [...] Ethnolinguistic studies regard language as a social and cultural instrument and try to uncover the cultural meaning behind linguistic structures and language use" (Foley 1997: 3). In this sense, "ethnolinguistics has variously been approached as the study of a group's experience of life as it is organized and expressed through the group's language tools and as a science whose aim is to examine the relationships between a language on the one hand and society and culture on the other" (Riley 2007: 8). However, the main focus of ethnolinguistics is the relationship between language and culture, communicative practices, and cognitive models of language and thought. It reaches many areas of linguistics, not only grammar and anthropological linguistics, but pragmatics and psycholinguistics as well: "The ethnolinguist tries to describe and understand the role of language in shaping the ways in which members of a group relate to the world, to one another and to others" (Riley 2007: 11).

Ethnosyntax is a closely related area of ethnolinguistics, but it presupposes a more abstract relation between culture, language and cognition. In our approach we used the term culture in its broadest sense: effects of environment-induced changes in

\footnotetext{
${ }^{1}$ The research reported on in this paper is funded by NKFIH (National Research, Development and Innovation Office, Hungary) in the frame of the project Ethnosyntactic Analysis of Siberian Uralic Languages (K129186, 2018-2021) at the University of Szeged, Hungary.

DOI https://10.14232/sua.2021.54.275-287
} 
language use that can cause change in the grammar. In our project the term ethnosyntax does not refer only to syntactic structures but to any environment-induced characteristics of the grammar. Ethnosyntax in our approach covers also partly ecolinguistics, which explores the role of language in the life-sustaining interactions of humans, other species and the physical environment. It is obvious that effect of culture and environment on grammar is more abstract that effect to the lexicon or language use and practice and the "exploration" of the direct motivation is more complicated. So, in this paper we argue that the ethnolinguistic (and, in a narrower sense, ethnosyntactic) approach to Uralic languages in the light of the most recent research can add new results in the study of Uralic languages.

\section{Uralic traditions in ethnolinguistics}

Our ethnolinguistic research uses the earliest works of Uralic linguistics as its antecedents whose outlook defined Finno-Ugric linguistics for a long time. Research into the syntax of endangered Uralic languages in Russia has recently acquired a focus on contact linguistics, on the effects of language loss on syntax, primarily from a generative perspective (e.g. publications of RIL HAS, see http://www.nytud.hu/oszt/elmnyelv/urali/publ.html), and the number of syntactic descriptions carried out with a typological perspective has increased (cf. WagnerNagy et al. 2015; de Groot 2017, Bíró and Sipőcz 2017). These studies have yielded important findings and, in several cases, have provided new insights into significant historical relationships as well (cf. É. Kiss 2014). However, they also lacks a number of approaches which are present in mainstream linguistic research today, such as the newest trends in anthropological linguistics, the use of cognitive linguistic perspectives in comparative linguistics, or that of specialized ethnolinguistic research.

The roots of ethnolinguistic research in Uralic linguistics go back to the life works of Pál Hunfalvy, Bernát Munkácsi, and Antal Reguly (Gulya 1970/1978). At the same time, a lot of research was conducted also by Finnish and German scholars as well, e.g. Artturi Kannisto, Toivo Lehtisalo, Wolfgang Steinitz, Yrjö Wichmann. Following Hymes (1965), Gulya overviews the areas of ethnolinguistic research stating that ethnolinguistics "[is a linguistic] method of analysis which, while focusing on language, includes in the research the investigation of the people, society, and culture using the language and their histories in a complex and comprehensive manner" (Gulya 1978: 134). In Uralic linguistics, ethnolinguistic research has been successfully carried out on the lexicon (cf. Steinitz's research on kinship terms).

In the late 20th century, with the development of anthropological linguistics (cf. Duranti 1997, 2004) and the spreading of ethnolinguistics beyond the lexicon, new directions emerged, such as ethnopragmatics, ethnosemantics, and ethnosyntax. The term ethnosyntax has been widely known since Wierzbicka's 1979 study and became 
a reference point through Enfield's 2002 volume. As a result of the latter, individual chapters in international handbooks of linguistics have been devoted to ethnolinguistic research (cf. Gladkova 2015).

In the present project we aim, on the one hand, to continue the (morpho)syntactic research tradition of Uralic linguistics (into syntactic change in endangered Uralic languages, contact effects in syntax etc.), and, on the other, to provide insight into new aspects of linguistic phenomena.

\section{The languages and corpora}

The project focuses on two related languages spoken in Siberia: Mansi, an Ob-Ugric language, and Nganasan, a Samoyedic language. Despite the fact that they both belong to the same language family (Uralic) and are spoken in the same linguistic area (Northwestern Siberia), the two languages exhibit great differences in their structure as well as in the ways of life and environment of their speakers. The latter include geographical and climatic differences, which also result in differences in traditional lifestyle, culture, and religion. The investigated languages are severely endangered, their speakers typically Russian-Mansi and Russian-Nganasan bilinguals with Russian as their dominant language.

The two investigated languages differ greatly in the amount of linguistic resources available. Mansi has been documented much more extensively (due to long time research traditions), whereas Nganasan has been documented mostly in the past few decades only. Our research will be carried out on the material included in databases and corpuses compiled in recent years, partly by the project participants:

- the NSL Corpus (a corpus available through the University of Hamburg, containing 294 texts, with 40,235 sentences from 55 speakers, of which about 20,279 sentences have been glossed so far) Version 0.2 of the corpus is available online (Brykina et al. 2018).

- OUL and OUDB: glossed Mansi texts available online (http://www.babel.gwi.uni$\underline{\text { muenchen.de/index.php?abfrage=NM_corpus\&subnavi=corpus_pub) }}$ 


\section{The focus of the analysis}

The following issues are investigated in the project.

\subsection{The ethnolinguistic background of linguistic means of perspectivization}

Perspectivization and subjectification can be expressed with a variety of linguistic means: lexically, syntactically, morphologically, and in a combination of these ways. (How a language expresses it is often dependent on categories such as epistemic modality and evidentiality.) A typical and most explicit way of perspectivization is direct quotation/speech. Descriptions of types of reported speech are abundant in the typology literature (cf. for instance Aikhenvald 2011, Li 1986), but data on small Uralic languages is completely missing from these. The works cited above also refer to the fact that there are language specific systems whose development is affected by cultural factors and/or contact effects. Our research partly focuses on uncovering such connections, namely, whether the development of reported speech (or lack thereof), the use of evidential morphological systems, and of markers of epistemic modality has been affected by such factors. We have already carried out investigations along these lines (Szeverényi 2017, Szeverényi and Sipőcz 2019), and have examined reported speech structures of Nganasan and Mansi. We also examined whether areal - primarily Russian - influence can be found in these structures. Indirect reported speech structures are rare in both languages, but sporadic data can be found in the corpus for them. In Mansi and Nganasan the direct reported speech structure is much more common than the indirect one. It can be observed that in Finno-Ugric languages the direct speech structure consisting of two clauses requires a subordinate conjunction. This is missing from these languages, although there are examples in our corpus for the adoption of the Russian conjunction što 'that'. In Mansi, in addition to the direct structure we can find the indirect structure without a conjunction, and a nonfinite structure can be used, too. In Nganasan the evidential (reportative) mood serves as an alternative.

There are many studies in the linguistics literature that can serve as models for a complex analysis of perspectivization and passive structures, however, their connection with evidentiality has not been explored yet. Evidentiality as a grammatical category has appeared in the description of Ob-Ugric languages only in recent years. Our research into Mansi quotative structures also indicated a need to carry out further research into evidentiality.

It is a significant fact that participles are used with an evidential function in the Northern dialect of Mansi, and there is such data only for this dialect in the literature. 
A similar observation has been made about Khanty, the closest related language of Mansi (Csepregi 2014). Analysis of the dialect data is ongoing, with texts from the Southern dialect not containing use of the evidential (Eastern dialect data is under analysis). All this is indicative of interesting historical, areal and cultural interconnectedness: the question arises whether the development of evidentiality is an areal phenomenon and/or internal development, given the fact that it happened only in the Northern dialects of Ob-Ugric languages. Bernárdez's cultural linguistic connections are important in both explanations, both in Nganasan and Mansi.

\subsection{The event of giving in an ethnolinguistic framework}

Investigating the event of giving in an ethnolinguistic framework has been an integral part of our previous research, in which ditransitive constructions in Mansi were investigated primarily from a typological perspective (K-101652). The event of giving has been studied in the literature on ethnosyntax as well. In one of his papers Newman (2002) distinguishes three categories of 'give' phenomena crosslinguistically from an ethnosyntactic perspective.

Ditransitive constructions in the Mansi language (and, in general, in Ob-Ugric languages, and some of the Samoyedic languages) display several characteristics which can be considered language specific: the alternation of indirective and secundative as well as of active and passive constructions (cf. Bíró and Sipőcz 2017). This is not rare typologically and can be considered a language specific feature that is independent of culture or of the environment. A more specific feature of Ob-Ugric ditransitive constructions is the full scale alternation of the two types of constructions (indirective and secundative) practically independently of lexical or semantic limitations. Moreover, a unique language specific feature of these languages (not discussed in the literature at all) is that the events of both giving and receiving are ditransitive and expressed with the verb 'give'. It is the secundative (R passive) construction involving the verb 'give' that expresses this event:

(1) Kitit mesta-l Nižnewartowskij $\bar{u} s-t$

second place-INSTR

Nizhnevartovsk town-LOC

$\bar{l} l-n e$ xanto-t maj-we-s-at.

live-PTCP.PRS

Khanty-PL give-PASS-PST-3PL

'The Khanty people from Nizhnevartovsk got the second place.' ('The second place was given to the Khanty people from Nizhnevartovsk.')

Our more recent research into language use demonstrates that, under the influence of the Russian language, certain verbs - such as 'take' and 'carry' - are beginning to acquire the meaning of 'receive'. Such usage frequently occurs in, for instance, translations from Russian. Such influence can fundamentally affect the system of rules 
underlying the alternation of ditransitive constructions.) (For more on this, see Sipöcz in this volume.)

\subsection{Spatial expresssions from the perspective of ethnosyntax}

The aim of our investigations into spatial expressions is to analyze the cultural background of a unique spatial orientation system found in Khanty, Mansi and Selkup: an adverb/preverb pair meaning 'toward/away from the river(bank)'; 'up to/down from the hill' and 'toward/away from the fire(place)'. This research is partly based on earlier literature on this topic, but our main aim is to also present new data from native speakers and recently assembled language corpora. Additionally, we make an attempt to identify similar phenomena in other languages of the area in order to give an explanation of this lexical orientation system. Several sources have been used for this investigation. In the case of Selkup, beside the lexicographical sources, the Selkup Spoken Language Corpus was also used. In the case of Khanty and Mansi, in addition to dictionaries, an Ob-Ugric Database was used. In addition, we collected data from the Mansi newspaper Lüimà Séripos and from native speakers of Mansi. We can state that the investigated Khanty, Mansi, and Selkup orientation subsystems are results of independent but contact induced parallel development, however, following Fortescue (2011), language contact cannot be regarded as the only explanation, because similar systems can be detected in North American languages as well. The development of these orientation systems was motivated by the particular geographic circumstances of the speakers, namely, living on steep river banks, and also by the fact that fire and water play a central role in their way of thinking. The orientation system is in correlation with the traditional way of life of the indigenous peoples of Western Siberia. The source concepts of the system are connected to the rivers and the dwellings, namely, the ancient cave dwellings on the upper part of the river bank.

Our research into this topic was summarized in a paper published in 2019 (Bíró et al. 2019). We plan to augment it with a description in the cognitive metaphor theoretical framework of cultural linguistics.

\subsection{Diminutives}

Diminutive derivational suffixes are used in many languages and present interesting examples of language phenomena which encode cultural rules and meanings. Extensive research has been done on such aspects of Slavic languages (Gladkova 2015, Wierzbicka 1979). In our research we use such investigations as our starting point, which is motivated especially by the fact that Siberian Uralic languages are under the continuous and heavy influence of the Russian language. In Mansi, two

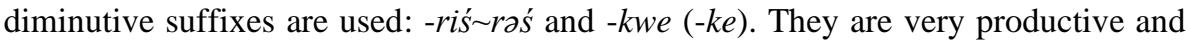


can be attached to any word with the exception of conjunctions (Rombandeeva 1973: 176). A curious feature of Mansi is that these diminutive suffixes occur also in verb conjugation as well, attaching to any verb stem, with the possibility that then genus, tense and mood inflections can also attach to them. When attached to verbs, they serve to express subjectivity: $-k w e(-k e)$ expresses the speaker's positive stance and adds a meaning of affection and politeness to the verb, while -riś $\sim$ raś expresses regret and scorn (Rombandeeva and Vahruseva 1989: 140, Riese 2001: 59), e.g. toti-ke-m 'I gladly bring', toti-ke-n! 'bring some, dear!', toti-riś-əm 'I bring poor (it is hard for me)', tājo-riś-en! 'eat (you poor, pitiable hungry wretch)!' (Munkácsi 1984: 40, Kálmán 1989: 56, 61). Some authors (Munkácsi 1894, Kálmán 1975) treat these forms as a separate mood ("affectionate" and "precative" or "kedveskedő" and "Präcativ" mood, respectively, in the originals), while others (e.g. Rombandeeva 1973, Rombandeeva and Vahruseva 1989, and Riese 2001) treat them as simple derived forms. In the case of nouns derived with the two diminutive suffixes, the positive and

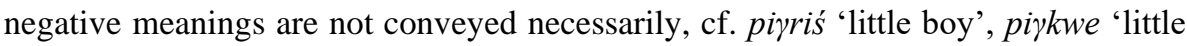
boy'.

The aim of our analysis is to establish exactly what principles govern the use of diminutive suffixes, and to show what cultural phenomena are behind these principles, as well as to ascertain whether the positive and negative meanings associated with the two derivational suffixes are really so clearly separable. (For more details, see Bíró in this volume).

\section{An example: cultural explanation of Nganasan evidentiality}

In this section we illustrate a detailed description of a grammatical feature with a possible cultural explanation, namely, the interaction of a subsystem of the grammar and the environment. Our hypothesis is that the complex evidentiality system in Nganasan has been formulated only in the northernmost Arctic area. We apply Bernárdez's hypothesis (2017) on a cultural explanation of evidentiality. Our research questions here are as follow:

(a) Does the investigation strengthen Bernárdez's cultural interpretation of evidentiality?

(b) What is the role of evidentiality in perspectivization?

Evidentiality in linguistics concerns how the source of knowledge is expressed in linguistic communication, whether grammatically coded, lexically coded, or merely inferred (Ekberg and Paradis 2009: 5). Bernárdez has a hypothesis (2017) about the cultural interpretation of evidentiality. Previously, some scholars have already referred to the possible connections between culture and evidentiality, e.g. Aikhenvald wrote that "[s]peaking a language with obligatory evidentials implies adhering to strict 
cultural conventions. Beliefs, mental attitudes, and patterns of behaviour appear to correlate with these" (Aikhenvald 2004: 361). Bernárdez was the first who found some correlations between environment, culture and evidentiality. His main findings are as follows:

A complex evidential system can be developed in connection with the following factors:

- "Small groups living in isolated environments enhance the probability of developing evidentials;

- Difficulties in accessing the world around enhance the probability of developing evidentials;

- Very tight relations within the group and with neighbouring groups also enhance the probability of developing evidentials." (Bernárdez 2017)

He established a small set of culturally determined principles:

(1) Every member of the community knows - to a greater or lesser degree - all, or most other members.

(2) Members of the community trust each other - except perhaps in a few cases.

(3) Sincerely telling (what one believes to be) the truth is a basic principle of behaviour in the community.

(4) Whenever someone cannot say that something has been directly experienced, s/he will say that what is being told is indirect experience, inference, etc.

In Uralistics and language typology it is a well-known fact that the Nganasan language (and languages closely related to it, such as Nenets and Enets) has a complex evidential system with the following basic distinctions:

direct evidential: unmarked indicative (the speaker perceives the event)

indirect evidentials: inferential

sensitive (the speaker perceives by hearing, touching or smelling)

narrative/reportative (hearsay or reported by other poeple)

These categories are inflectional and expressed by suffixes.

This kind of evidentiality is most typical in South America (e.g. Tucanoan languages) and among the languages of Papua New Guinea, but it has never been investigated in the Arctic. We argue that maintaining the culturally determined viewpoint is the crucial point in the development of evidential system, and its effect on other parts of the grammar that cover the means of perspectivization. "Perspectivization is a mode of perception and representation constitutes a basic disposition of the human mind, the relationship between perspectivization and narrativity is particularly close as narratives are characterized by the fact that a 
narrator functions as an instance of mediacy which refracts the story" (Zeman 2016: 2 ). The most frequent approach refers to perspectivization in terms of the focalization models and the question 'who sees' vs. 'who perceives'. Perspectivization means how the information is connected to concrete or abstract cognisant entities other than the speaker, while subjectification is about how the information in an utterance is connected to the speaker by the use of expressive predicates (Sanders and Spooren 1997). Evidentials are the typical means of perspectivization that can combine perspectivization and subjectification:

- First, they refer to a subject of consciousness other than the present speaker, to whom the responsibility for the utterance must be attributed (perspectivization).

- Evidentials are perspectivizing in that they present an event from the point of view of an evidential origo (the perspective holder).

- Second, they express some degree of certainty with respect to the utterance in the current speaker (subjectification).

Means of perspectivizing can be reported speech constructions, evidentials, deictic elements (e.g. spatial, temporal), lexically coded elements (e.g. antonyms: come/go, give/get etc.), passivization (derivational suffix), and deontic modals.

Reported speech is the most explicit form of perspectivization, because it inherently involves perspectivization: with the subject of consciousness positioned in the speaker of the embedded rather than the matrix utterance. In direct speech, the embedded speaker is made responsible for the form as well as the propositional content of the quoted utterance, in indirect speech s/he only accounts for the latter (Tátrai and Csontos 2009). In Nganasan only direct speech constructions exist without shifts. Principally, in reported speech the following shifts seem to be possible on the morphological level:

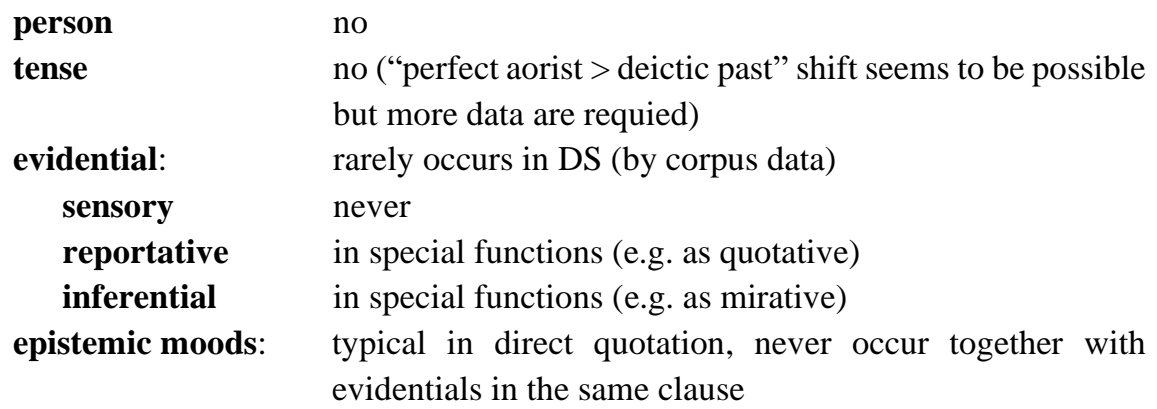

These features confirm Bernárdez's hypothesis on evidentiality. The current speaker is always the perspective holder who is not responsible for the utterance of 
the original speaker. The current speaker can determine the type of source of information from his own point of view. Epistemic moods and lexemes in the speech of the actual speaker occur always verbatim as the part of the quoted sentence. Nganasan fits the cultural interpretation of evidentiality (Bernárdez 2017), where evidentiality plays a fundamental role in perspectivization. The first results show that there is a strong correlation among the investigated features. A Nganasan speaker almost always marks his/her "responsibility" for the truth of an utterance. This kind of responsibility mirrors in occurrence of epistemic and evidential elements in the speech of current vs. original speakers. With terms of functional cognitive pragmatics - the move of the referential center is the crucial point in the organization of a narrative and discourse. The current speaker marks his/her own perspective (evidential origo). The shiftless deictic elements serve this rigid system: the speaker keeps the referential center or moves it totally to the embedded speaker.

\section{References}

Aikhenvald, Alexandra Y. 2004. Evidentiality. Oxford: Oxford University Press.

Aikhenvald, Alexandra Y. 2011. Speech reports: A cross-linguistic perspective. In: Alexandra Aikhnevald and Robert Malcolm Dixon (eds.), Language at large. Leiden and Boston: Brill, 290-326.

Bernárdez, Enrique 2017. Evidentiality - a cultural interpretation. In: Farzad Sharifian (ed.), Advances in cultural linguistics. Singapore: Springer, 433-460.

Bíró, Bernadett, Sipőcz, Katalin, and Szeverényi, Sándor 2019. Nyugat-szibériai uráli nyelvek térbeli orientációs rendszere [The spatial orientation system of Western Siberian Uralic languages]. Folia Uralica Debreceniensia 26: 29-44.

Bíró, Bernadett and Sipőcz, Katalin 2017. Ditransitivity in the Mansi language from a typological perspective. Finnisch-ugrische Mitteilungen 41: 25-43.

Brykina, Maria, Gusev, Valentin, Szeverényi, Sándor, and Wagner-Nagy, Beáta 2016. Nganasan Spoken Language Corpus (NSLC): Archived in Hamburger Zentrum für Sprachkorpora. Version 0.1.

Brykina, Maria, Gusev, Valentin, Szeverényi, Sándor and Wagner-Nagy, Beáta 2018. "Nganasan Spoken Language Corpus (NSLC)." Archived in Hamburger Zentrum für Sprachkorpora. Version 0.2. http://hdl.handle.net/11022/00000007-C6F2-8.

Busser, Rik De 2015. The influence of social, cultural, and natural factors on language structure. In: Rik De Busser and Randy J. LaPolla (eds.), Language structure and environment. Amsterdam and Philadelphia: John Benjamins Publishing, $1-28$. 
Csepregi, Márta 2014. Evidencialitás a hanti nyelvjárásokban In: Havas, Ferenc, Horváth, Katalin, Kugler, Nóra and Vladár, Zsuzsa (eds.), Nyelvben a világ. Tanulmányok Ladányi Mária tiszteletére [The world in language: Studies in honor of Mária Ladányi]. Segédkönyvek a magyar nyelvészet tanulmányozásához 160. Budapest: Tinta Könyvkiadó, 99-109.

De Groot, Casper (ed.) 2017. Uralic essive and the expression of impermanent state. Amsterdam: John Benjamins.

Deutscher, Guy 2010. Through the language glass: Why the world looks different in other languages. New York: Picador.

Duranti, Alessandro 1997. Linguistic anthropology. Cambridge: Cambridge University Press.

Duranti, Alessandro (ed.) 2004. A companion to linguistic anthropology. Oxford: Blackwell.

É. Kiss Katalin (ed.) 2014. Magyar generatív történeti mondattan [A generative historical syntax of Hungarian]. Budapest: Akadémiai Kiadó

Ekberg, Lena and Carita Paradis. 2009. Evidentiality in language and cognition. Editorial paper to special issue. Functions in Language 16(1): 5-7.

Enfield, Nick J. (ed.) 2002. Ethnosyntax: Explorations in grammar and culture. Oxford: Oxford University Press.

Foley, William 1997. Anthropological linguistics: An introduction. Oxford: Blackwell.

Gladkova, Anna Nikolaeva 2015. Ethnosyntax. In: Sharifian, Farzad (ed.), The Routledge handbook of language and culture. Abingdon Oxon UK: Routledge, 33-50.

Gulya, János 1970. Az etnolingvisztika magyar elöfutárai [Hungarian precursors of ethnolinguistics]. In: Szathmári, István (ed.), Tanulmányok a magyar és finnugor nyelvtudomány történetéből [Studies on the history of Hungarian and Finno-Ugric linguistics] Budapest: Tankönyvkiadó, 131-135.

Gusev, Valentin 2007. Эвиденциалность в нганасанском языке. In: Эвиденцииальность в языках Европь и Азии. Сборник статей памяти Н. А. Козинцевой. СПб.: Наука, 415-444.

Heine, Bernd. 1997. Cognitive foundations of grammar. New York: Oxford University Press.

Kálmán, Béla 1989. Chrestomathia Vogulica. Budapest: Tankönyvkiadó.

Kulonen, Ulla-Maija 1985. A perspektíva és a vogul szenvedő szerkezet [Perspective and the Mansi passive construction]. Nyelvtudományi Közlemények 87: 217224.

Kulonen, Ulla-Maija 1989. The passive in Ob-Ugrian [SUST 203]. Helsinki: Suomalais-Ugrilainen Seura. 
Li, Charles N. 1986. Direct and indirect speech: A functional study. In: Florian Coulmas (ed.), Direct and indirect speech. Trends in linguistics studies and monographs 31, New York: Mouton de Gruyter, 29-45.

Miestamo, Matti, Tamm, Anne and Wagner-Nagy, Beáta (eds.) 2015. Negation in Uralic languages. Amsterdam and Philadelphia: John Benjamins.

Munkácsi, Bernát 1894. A vogul nyelvjárások szóragozásukban ismertetve [Inflection in Vogul dialects]. Budapest: MTA.

Newman, John 2002. Culture, cognition, and the grammar of 'give' clauses. In: N. J. Enfield (ed.). Ethnosyntax: Explorations in grammar and culture. Oxford: Oxford University Press.

Riese, Timothy 2001. Vogul. Languages of the World/Materials 158. Muenchen: Lincom Europa.

Riley, Philip 2007. Language, culture and identity: An ethnolinguistic perspective. London and New York: Continuum.

Rombandeeva, Evdokia Ivanovna, and Vahruseva, M. Р. [Ромбандеева, Евдокия Ивановна - Вахрушева, М. П.] 1989. Mansijskij jazyk [Мансийский язык]. Ленинград: Просвещение Ленинградское отделение.

Rombandeeva, Evdokia Ivanovna [Ромбандеева, Евдокия Ивановна] 1973. Mansijskij (vogulskij) jazyk [Мансийский (вогульский) язык.] Москва: Издательство «Наука», 65-79.

Sanders, José and Wilbert Spooren 1997. Perspective, subjectivity, and modality from a cognitive linguistic point of view. In: Liebert, Wolf-Andreas, Gisela Redeker and Linda R. Waugh (eds.), Discourse and cerspective in cognitive linguistics. Amsterdam and Philadelphia: John Benjamins, 85-112.

Szeverényi, Sándor 2017. Egy nganaszan episztenciális finit ige lexikalizációja [The lexicalization of a Nganasan epistential finite verb]. In: Forgács, Tamás, Németh, Miklós and Sinkovics, Balázs (eds.), A nyelvtörténeti kutatások újabb eredményei IX [New findings in historical linguistics, vol. 9]. Szeged: SZTE, 303-317.

Szeverényi, Sándor and Sipőcz, Katalin 2019. Szibériai uráli nyelvek idéző szerkezetei [Quotative structures in Uralic languages in Siberia]. In: É. Kiss, Katalin, Hegedűs, Attila, and Pintér, Lilla (eds.) Nyelvelmélet és kontaktológia 4 [Linguistic theory and contact linguistics, vol. 4]. Budapest and Piliscsaba: PPKE BTK. 127-146.

Tátrai, Szilárd and Csontos, Nóra 2009. Perspectivization and modes of quoting in Hungarian. Acta Linguistica Hungarica 56(4): 441-468.

Wierzbicka, Anna 1979. Ethno-syntax and the philosophy of grammar. Studies in Language 3(3): 313-383. 
Zeman, Sonja 2016. Introduction. In: Igl, Natalia and Zeman, Sonja (eds.) 2016. Perspectives on narrativity and narrative perspectivization. Amsterdam and Philadelphia: John Benjamins. 1-14. https://doi.org/10.1075/lal.21 